\title{
PERANCANGAN PROGRAM APLIKASI PENENTUAN PORTOFOLIO INVESTASI DENGAN METODE DEMPSTER SHAFER FUZZY-ANALYTICAL HIERARCHY PROCESS
}

\author{
Rojali; Syaeful Karim; Edgar Gerriano
}

\author{
Jurusan Matematika, Fakultas Sains dan Teknologi, Binus University \\ Jln. K.H. Syahdan No. 9, Palmerah, Jakarta Barat 11480 \\ rojali@binus.edu \\ Jurusan Teknik Informatika, Fakultas Ilmu Komputer, Binus University \\ Jln. K.H. Syahdan No. 9, Palmerah, Jakarta Barat 11480
}

\begin{abstract}
Investment is very popular nowadays to gain profits of the available property. Many investment portfolios are available but there are still a handful of users who have not been able to determine the best type of investment. Surely it would be very unfortunate if the property can not be well invested. Therefore, it is necessary to propose another alternative method that can determine the existing investment portfolio. This method begins by a process which details existing factors in every investment portfolio. Then, it takes intuition properly to give weight to the initial calculation. After that, it takes a Fuzzy concept as a tool to provide a numerical weight to each of the parameters. The final step is weighting process using Dempster Shafer method. With the use of three basic concepts, investors are expected to obtain objective and optimal computing results related to the profitable investment portfolio selection.
\end{abstract}

Keywords: investment, optimal, Dempster Shafer, Fuzzy, Analytical Hierarchy Process.

\begin{abstract}
ABSTRAK
Investasi sangat populer saat ini untuk mendapatkan keuntungan dari harta yang tersedia. Banyak portofolio investasi tersedia tetapi masih terdapat segelintir penggunanya yang belum dapat menentukan jenis investasi yang terbaik. Tentunya akan sangat disayangkan apabila harta tersebut tidak dapat diinvestasikan dengan baik. Oleh karena itu, perlu untuk mengusulkan alternatif metode lain yang dapat menentukan portofolio investasi yang ada. Metode ini diawali dengan merinci faktor-faktor yang ada pada tiap portofolio investasi. Lalu, dibutuhkan intuisi yang tepat untuk memberikan bobot pada awal perhitungan. Dilanjutkan dengan konsep Fuzzy sebagai piranti numerik yang berperan untuk memberikan bobot pada tiap parameter yang ada. Tahapan akhirnya dengan mengolah pembobotan tersebut dengan metode Dempster Shafer. Dengan digunakannya ketiga konsep dasar di atas, diharapkan investor dapat memperoleh hasil komputasi optimal objektif yang berkaitan dengan pemilihan portofolio investasi yang menguntungkan.
\end{abstract}

Kata kunci: Investasi, optimal, Dempster Shafer, Fuzzy, Analytical Hierarchy Process. 


\section{PENDAHULUAN}

\section{Latar Belakang}

Dalam bidang perekonomian, uang merupakan salah satu bentuk dari harta. Dalam kehidupan sehari-hari, manusia tentu tidak dapat melepaskan diri dari harta. Harta adalah sesuatu yang sangat penting dalam kehidupan manusia. Karena begitu penting dan berharganya, manusia seringkali berlomba untuk mengumpulkan harta sebanyak-banyaknya. Bahkan seringkali pula menghalalkan segala cara untuk mendapatkannya. Hal tersebut sangatlah wajar, mengingat sifat manusia sebagai makhluk homo economicus.

Homo economicus adalah sebutan orang awam terhadap mereka-mereka yang senantiasa berorientasi pada profit, produktivitas, modal, dan hal-hal yang berbau materi lainnya. Homo economicus berasal dari bahasa Latin yang artinya manusia ekonomi. Jika pengertian kata 'ekonomi' sendiri dipahami dengan lebih mendalam, maka dapat ditemukan bahwa arti dari homo economicus tidaklah seperti yang selama ini orang awam pandang secara sempit, melainkan akan merujuk kepada sebuah sosok manusia yang rasional dan berkebebasan dalam menentukan pilihan-pilihan yang ada untuk mencapai tujuan tertentu. Dari pengertian tersebut, maka dapat ditemukan bahwa pada dasarnya setiap orang adalah manusia ekonomi. Pada kehidupan sehari-hari, bukan hanya para ekonom, pebisnis, ataupun akademisi bidang ekonomi saja yang dapat disebut manusia ekonomi atau homo economicus.

Didasari oleh salah satu sifat manusia yang telah dijelaskan di atas, sangatlah relevan apabila manusia berlomba-lomba untuk menginvestasikan harta dengan berbagai macam bentuk dan cara supaya dapat menghasilkan keuntungan yang maksimal. Harta tentunya akan menguntungkan apabila diinvestasikan dalam bentuk yang benar. Alangkah baiknya apabila harta diinvestasikan secara benar, sehingga dapat menguntungkan bagi pemiliknya. Apabila diperhatikan lebih lanjut, tanpa disadari ternyata banyak individu pada zaman sekarang ini yang memiliki harta berlimpah.

Pertanyaan yang muncul adalah, apakah semua dari mereka mengetahui secara seksama bagaimana cara menginvestasikan hartanya dalam bentuk yang benar. Karena pada umumnya, mereka menginvestasikan harta mereka berdasarkan intuisi semata, tanpa melibatkan data-data numerik yang tentunya dapat menguatkan pilihan investasi yang lebih menguntungkan. Adapun fakta di lapangan, pada akhirnya intuisi dan pengalaman yang mendasari pemilihan bentuk investasi. Alangkah lebih baik apabila pemilihan bentuk investasi tidak hanya didasari oleh kedua parameter tersebut saja, melainkan ikut memperhitungkan tentang data-data otentik, faktor-faktor yang dipersempit, serta berbagai penilaian lainnya.

Mengacu pada latar belakang masalah di atas, beberapa masalah yang dapat dikemukakan antara lain: (1) metode yang digunakan dalam menentukan keputusan investasi; (2) faktor-faktor yang berhubungan dengan analisa jenis investasi berdasarkan metode yang dipakai; (3) menentukan jenis investasi apa saja yang layak dipilih berdasarkan hasil perhitungan. Sistem yang digunakan dalam metode merupakan sistem perhitungan secara numerik berdasarkan konsep Fuzzy, sehingga didapat angka-angka yang merupakan bobot pada setiap usulan investasi yang dipertimbangkan.

Angka-angka yang menjadi bobot berkisar antara 0 sampai 1, karena digunakan konsep Fuzzy dalam metode ini. Faktor-faktor yang mempengaruhi pertimbangan usulan investasi dipecah menjadi beberapa bagian sesuai konsep Analytical Hierarchy Process. Perhitungan bobot akhir dihitung menggunakan Dempster's Rules of Combination yang merupakan metode yang diterapkan, yaitu Dempster Shafer. 


\section{Tujuan dan Manfaat}

Tujuan dari perancangan yang dilakukan adalah untuk mengetahui jenis investasi yang paling menguntungkan berdasarkan perhitungan dengan metode Dempster Shafer Fuzzy Analytical Hierarchy Process (DSF-AHP). Manfaat dari perancangan ini adalah untuk membantu para investor memilih portofolio investasi yang paling menguntungkan di antara pilihan-pilihan yang ada dengan metode DSF-AHP. Bagi penulis, manfaatnya adalah untuk menambah pengetahuan dan untuk mengetahui lebih dalam mengenai metode dan aplikasinya dalam kehidupan. Bagi peneliti, manfaatnya adalah sebagai suatu pandangan baru menyangkut aplikasi metode di atas. Selanjutnya, bagi pembaca, manfaat dari makalah ini adalah untuk menambah pengetahuan teknis mengenai optimalisasi terhadap jenis investasi yang ada berdasarkan faktor-faktor yang mempengaruhinya.

\section{Tinjauan Pustaka}

\section{Investasi}

Investasi adalah salah satu istilah ekonomi dengan beberapa pengertian yang berhubungan dengan keuangan. Istilah tersebut berkaitan dengan akumulasi suatu bentuk aktiva dengan suatu harapan mendapatkan keuntungan di masa depan. Terkadang, investasi disebut juga sebagai penanaman modal.

Portofolio investasi dewasa ini sudah ada banyak ragamnya, misalnya investasi dalam bentuk uang asing (dolar), tanah, emas, perak, saham, dan lain-lain. Apabila ditelaah lebih lanjut, tiap investasi dipengaruhi oleh beberapa faktor, misalnya tingkat kenaikan nilai investasi, kemudahan dalam penjualan kembali, tingkat stabilitas, fluktuasi nilai investasi, dan lain-lain. Faktor-faktor inilah yang mempengaruhi kualitas suatu jenis investasi.

\section{Logika Fuzzy}

Logika Fuzzy merupakan peningkatan dari logika Boolean yang berhadapan dengan suatu konsep kebenaran tidak penuh (sebagian), dimana peran logika klasik menyatakan bahwa segala hal dapat diekspresikan dalam istilah binary (0 atau 1, hitam atau putih, ya atau tidak). Logika Fuzzy menggantikan kebenaran Boolean dengan tingkat kebenaran. Logika ini juga memungkinkan nilai keanggotaan antara 0 dan 1, tingkat keabu-abuan, dan juga hitam dan putih, dan dalam bentuk linguistik, pandangan tidak pasti seperti "sedikit", "lumayan", dan "sangat". Hal ini erat kaitannya dengan set Fuzzy dan teorema kemungkinan. Tanpa disadari, logika Fuzzy banyak digunakan dalam kehidupan sehari-hari, karena logika ini mengadopsi pemahaman serta penilaian otak manusia terhadap suatu hal tertentu. Dalam kehidupan sehari-hari, manusia banyak dihadapi dengan situasi pertimbangan yang tidak pasti jawabannya ya atau tidak. Hal ini adalah salah satu contoh sederhana logika Fuzzy dalam kehidupan sehari-hari.

\section{Analytical Hierarchy Process (AHP)}

AHP merupakan salah satu metode matematik yang dikembangkan oleh ahli matematika Thomas L. Saaty (Gambar 1). Tujuan metode ini adalah untuk mengambil keputusan dengan efektif atas persoalan yang kompleks dengan cara menyederhanakan dan mempercepat proses pengambilan keputusan (Latifah, 2005). Dilanjutkan dengan memecahkan persoalan tersebut kedalam bagianbagiannya, menata bagian atau variabel ini dalam suatu susunan hirarki, serta memberi suatu nilai numerik pada pertimbangan subjektif tentang pentingnya tiap variabel. Tahap akhirnya yaitu dengan mensintesis berbagai pertimbangan ini untuk menetapkan variabel yang memiliki prioritas paling tinggi dan bertindak untuk mempengaruhi hasil pada situasi tersebut. Metode AHP ini membantu memecahkan persoalan yang kompleks dengan menstruktur suatu hirarki kriteria, pihak yang berkepentingan, hasil dan dengan menarik berbagai pertimbangan guna mengembangkan bobot atau 
prioritas (Raharjo dan Sutapa, 2002). Metode ini juga menggabungkan kekuatan dari perasaan dan logika yang bersangkutan pada berbagai persoalan, lalu mensintesis berbagai pertimbangan yang beragam menjadi hasil yang cocok dengan perkiraan kita secara intuitif sebagaimana yang dipresentasikan pada pertimbangan yang telah dibuat.

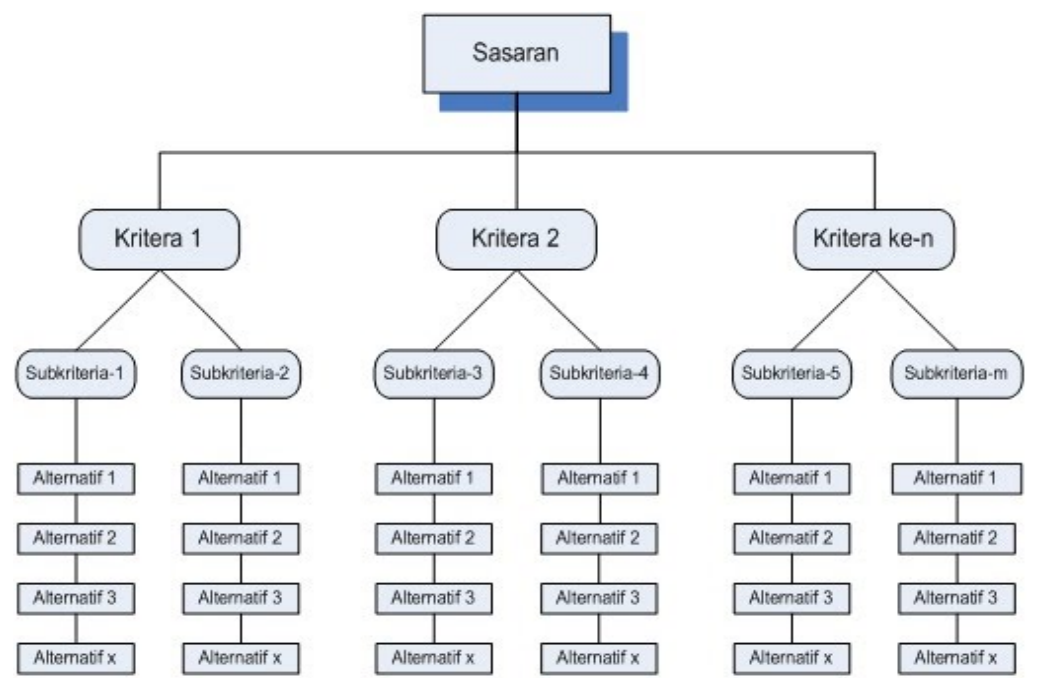

Gambar 1. Contoh AHP.

\section{Pemecahan Persoalan dengan AHP}

Menurut Saaty, AHP terdiri dari tiga prinsip utama dalam memecahkan persoalan, yaitu prinsip menyusun hirarki (decomposition), prinsip menentukan prioritas (comparative judgement), dan prinsip konsistensi logis (logical consistency). Kata hirarki yang dimaksud diatas adalah hirarki dari permasalahan yang akan dipecahkan untuk mempertimbangkan kriteria-kriteria atau komponenkomponen yang mendukung tercapainya suatu tujuan. Dalam memilih kriteria-kriteria pada setiap masalah pengambilan keputusan perlu memperhatikan hal-hal berikut: (1) lengkap - kriteria harus mencakup semua aspek, sehingga harus lengkap; (2) operasional - setiap kriteria harus mempunyai arti bagi pengambil keputusan, sehingga dapat relevan terhadap alternatif yang ada; (3) tidak berlebihan - kriteria yang mengandung pengertian yang sama harus dihindari; (3) minimum - dibuat minimum supaya mempermudah pemahaman persoalan.

\section{Decomposition}

Decomposition adalah pemecahan persoalan menjadi unsur-unsurnya, tentunya dilakukan setelah persoalan telah terdefinisi dengan baik. Jika ingin mendapatkan hasil yang lebih akurat, pemecahan dapat dilakukan terhadap unsur-unsurnya sehingga didapatkan beberapa tingkatan dari persoalan tadi. Karena itulah maka proses analisis ini dinamakan hirarki (hierarchy). Hirarki ada 2 macam, yaitu hirarki lengkap dan hirarki tidak lengkap. Hirarki lengkap adalah hirarki yang semua elemen pada semua tingkat memiliki semua elemen yang ada pada tingkat berikutnya. Selain dalam kondisi tersebut, dinamakan hirarki tidak lengkap.

\section{Comparative Judgement}

Prinsip ini bermaksud membuat penilaian tentang kepentingan relatif dua elemen pada suatu tingkat tertentu yang berkaitan dengan tingkat yang diatasnya. Penilaian ini merupakan inti dari AHP, 
karena akan mempengaruhi prioritas elemen-elemen. Hasil dari penilaian ini akan ditempatkan dalam bentuk matriks yang dinamakan matriks pairwise comparison (Sevastjanov, 2004).

Tahapan-tahapan dalam melakukan penilaian terhadap elemen-elemen yang diperbandingkan antara lain: (1) elemen mana yang lebih (penting/disukai/berpengaruh/lainnya); (2) seberapa (penting/disukai/berpengaruh/lainnya).

Perlu dipahami tujuan yang diambil secara umum agar diperoleh skala yang bermanfaat ketika membandingkan dua elemen. Penyusunan skala kepentingan menggunakan patokan pada Tabel 1 di bawah ini.

Table 1

Skala Kepentingan dan Penjelasannya

\begin{tabular}{|c|c|c|}
\hline $\begin{array}{c}\text { Intensitas } \\
\text { Kepentingan }\end{array}$ & Definisi & Penjelasan \\
\hline 1 & Kedua elemen sama pentingnya & $\begin{array}{l}\text { Dua elemen kontribusinya sama } \\
\text { terhadap elemen tersebut }\end{array}$ \\
\hline 3 & $\begin{array}{l}\text { Elemen yang satu sedikit lebih } \\
\text { penting }\end{array}$ & $\begin{array}{l}\text { Pengalaman dan pertimbangan sedikit } \\
\text { menyokong elemen atas lainnya }\end{array}$ \\
\hline 5 & $\begin{array}{l}\text { Elemen yang satu essensial (sangat } \\
\text { penting) }\end{array}$ & $\begin{array}{l}\text { Pengalaman dan pertimbangan kuat } \\
\text { menyokong elemen atas lainnya }\end{array}$ \\
\hline 7 & Elemen yang satu jelas lebih penting & $\begin{array}{l}\text { Satu elemen kuat disokong, } \\
\text { mendominasi praktek }\end{array}$ \\
\hline 9 & $\begin{array}{l}\text { Elemen yang satu mutlak lebih } \\
\text { penting }\end{array}$ & $\begin{array}{l}\text { Bukti yang menyokong elemen yang } \\
\text { atas memiliki nilai penegasan yang } \\
\text { sangat tinggi }\end{array}$ \\
\hline $2,4,6,8$ & $\begin{array}{l}\text { Nilai diantara dua pertimbangan yang } \\
\text { berdekatan }\end{array}$ & $\begin{array}{l}\text { Diperlukan kompromi antara dua } \\
\text { pertimbangan }\end{array}$ \\
\hline Kebalikan & $\begin{array}{l}\text { Nilai aktifitas elemen saling } \\
\text { berkebalikan }\end{array}$ & \\
\hline
\end{tabular}

\section{Logical Consistency}

Konsistensi memiliki dua makna. Yang pertama adalah objek-objek serupa dapat dikelompokkan sesuai dengan keseragaman serta relevansinya. Yang kedua adalah menyangkut tingkat hubungan antar objek-objek yang didasari oleh kriteria-kriteria tertentu (Sudarsono, 2004).

\section{METODE}

Perancangan ini menggunakan metodologi yang terbagi menjadi beberapa bagian. Bagian pertama adalah penentuan parameter penilaian untuk proses pengambilan keputusan. Parameter yang dimaksud adalah berbagai faktor yang ingin dibandingkan antara satu usulan investasi dengan usulan investasi lainnya. Parameter yang dibandingkan haruslah relatif sama hubungannya dengan setiap usulan investasi. Selain itu, parameter juga harus bersifat komparatif terhadap usulan investasi yang satu dengan usulan investasi yang lainnya. Selain itu, parameter juga harus bersifat komparatif terhadap usulan investasi yang satu dengan usulan investasi yang lainnya. Parameter ini mempengaruhi pembuatan hirarki untuk menentukan usulan investasi yang optimal. Hirarki yang terbentuk, haruslah memiliki bobot-bobot yang jelas, sehingga pada tiap parameter dapat diketahui porsi-porsinya. 
Bagian kedua adalah penentuan nilai tiap-tiap usulan investasi terhadap setiap parameter yang ada. Penilaian ini yang akan menjadi urutan usulan investasi pada setiap parameter yang ada sebagai urutan sementara. Setelah didapat urutan sementara usulan investasi di tiap parameter, dilakukan perhitungan dengan metode Dempster Shafer Fuzzy Analytical Hierarchy Process untuk menentukan matriks pada tiap parameter. Setelah mendapat hasil lengkap matriks tersebut, barulah dilakukan irisan sesuai dengan Dempster's rule of combination sehingga menghasilkan hasil kali pada tiap-tiap kemungkinan irisan yang terjadi.

Pada akhirnya, hasil tersebut akan dikelompokkan sesuai dengan hasil irisan usulan investasi yang terjadi. Hasil ini dapat diartikan sebagai urutan usulan investasi yang paling menguntungkan.

Pada perancangan program kali ini, data akan di-input oleh pengguna program. Ini dimaksudkan supaya memungkinkan para investor memasukkan data dari beragam aspek, terutama aspek waktu. Pada fakta di kehidupan sehari-hari, data akan berubah sewaktu-waktu. Penulis ingin memberikan kebebasan kepada para investor untuk dapat menggunakan aplikasi ini dengan berbagai macam jenis objek, serta berbagai jenis parameter yang ingin dibandingkan.

\section{HASIL DAN PEMBAHASAN}

\section{Metode Pengumpulan Data}

Data yang menjadi masukan program akan di-input oleh calon investor sehingga dapat dihitung lebih lanjut pertimbangan urutan prioritasnya. Pada aplikasi ini, penulis memberikan ruang seluas-luasnya kepada investor untuk meng-input berbagai kemungkinan data yang tentunya dapat dibandingkan. Ada berbagai cara investor dapat mengumpulkan data, antara lain melalui internet dan database badan penyedia data investasi.

\section{Permasalahan yang Dihadapi}

Dewasa ini, banyak sekali investor yang kurang memahami cara yang tepat untuk berinvestasi. Dan pada kenyataannya, mereka hanya mengandalkan intuisi dan pengalaman semata. Apabila ditelaah lebih lanjut, akan lebih baik apabila mengikutsertakan data otentik dalam perhitungan, agar didapat urutan prioritas yang lebih terpercaya. Investorpun sering menghadapi kebingungan saat memilih banyak jenis usulan investasi. Kebingungan ini ditambah lagi dengan banyaknya jenis parameter yang mempengaruhi kecenderungan prioritas pemilihan jenis investasi yang ada. Ini disebabkan karena adanya keterbatasan otak manusia untuk memperhitungkan pengaruh bobot pada tiap parameter terhadap setiap jenis usulan investasi yang memungkinkan. Maka dari itu program ini dibuat untuk memecahkan persoalan tersebut.

\section{Penyelesaian Masalah}

Didasari oleh perhitungan yang cukup rumit dan kemungkinan adanya para pengguna aplikasi yang tidak mengerti apabila ditampilkan secara mendetail proses-proses yang terjadi pada metode ini, maka aplikasi yang akan dibuat tidak menampilkan langkah mendetail metode secara keseluruhan. Dengan pertimbangan ini pula, program akan dibuat semudah mungkin digunakan, supaya dapat digunakan oleh hampir setiap orang yang ingin berinvestasi.

Secara global, program ini disusun untuk dapat mengaplikasikan metode Dempster Shafer Fuzzy Analytical Hierarchy Process (DSF-AHP) pada beberapa pertimbangan usulan. Dengan banyak input yang ada, diharapkan program ini dapat menghasilkan output, yaitu urutan prioritas usulan. 


\section{Analisis Objek Usulan Investasi dengan Metode Fuzzy Analytical Hierarchy Process}

Pada setiap usulan investasi, tentunya ada beberapa parameter yang ingin dibandingkan. Parameter yang dimaksud adalah suatu faktor pembanding antara usulan investasi yang satu, dengan usulan investasi yang lainnya. Tentunya, parameter yang dimaksud bersifat komparatif antara parameter usulan investasi yang satu dengan parameter usulan investasi yang lainnya. Misalnya usulan pertama adalah emas, usulan kedua adalah tanah, usulan ketiga adalah rumah, serta usulan keempat adalah dolar (kurs mata uang tertentu).

Untuk setiap parameter yang ingin dibandingkan, harus memiliki bobot masing-masing. Bobot pada tiap parameter harus berjumlah 1. Bobot tiap parameter tidak harus sama, tergantung dari pertimbangan investor. Prioritas parameter ditandai dengan besarnya bobot tiap parameter. Misalnya ada 3 parameter ( $\mathrm{a}, \mathrm{b}$, dan $\mathrm{c}$ ). Apabila parameter $\mathrm{A}$ merupakan separuh prioritas, parameter $\mathrm{B}$ merupakan sepertiga prioritas, dan parameter $\mathrm{C}$ adalah sisanya, maka pembobotan parameter $\mathrm{A}=0,5$; $\mathrm{B}=0,3 ; \mathrm{C}=0,2$ (apabila dijumlah, harus bernilai $1 ; 0,5+0,3+0,2=1$ ). Apabila digambarkan dalam bentuk hirarki, akan terlihat seperti pada Gambar 2 berikut.

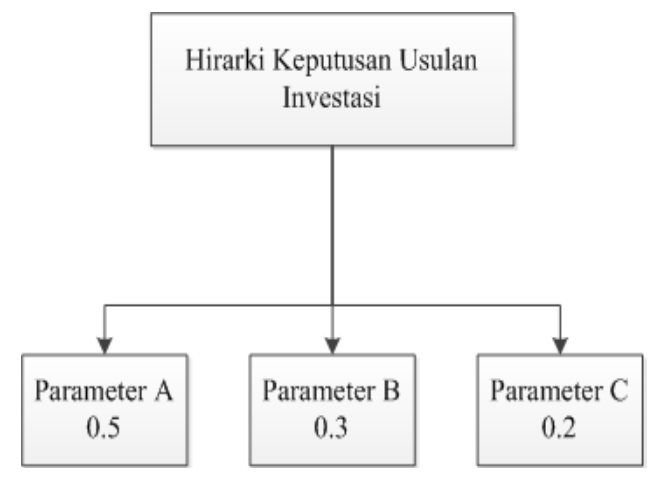

Gambar 2. Contoh bentuk hirarki Fuzzy analytical hierarchy process.

Setelah memberikan bobot pada tiap parameter dan telah dilakukan konfirmasi bahwa jumlah bobot tiap parameter adalah 1 , selanjutnya adalah penentuan jenis penilaian tiap parameter terhadap usulan investasi. Jenis penilaian ini dibagi menjadi dua, yaitu penilaian individu dan penilaian berdasarkan data. Penilaian individu adalah penilaian yang langsung diberikan oleh investor pada parameter di tiap usulan investasi. Penilaian ini dipakai supaya ada unsur intuisi dalam penilaian, bukan hanya semata-mata dari data saja. Unsur intuisi ini sangat dipengaruhi oleh pengalaman sang investor dalam menilai suatu parameter terhadap usulan investasi, sehingga diharapkan hasil perhitungan dari metode ini dapat lebih akurat dan terpercaya. Pada dasarnya, metode Dempster Shafer sendiri melibatkan unsur intuisi yang merupakan nilai lebih dibandingkan dengan metodemetode lainnya yang sejenis.

Penilaian berdasarkan data adalah penilaian yang didasari oleh data yang ada. Penilaian ini dibagi menjadi dua, yaitu penilaian $\max$ dan min. Penilaian $\max$ adalah penilaian dimana semakin besar data, semakin baik bobotnya. Contoh penilaian max antara lain perkembangan ekonomi, penilaian teknis, dan lainnya. Sedangkan penilaian min adalah penilaian dimana semakin kecil data, semakin baik bobotnya. Adapun contoh penilaian $\min$ antara lain resiko penyusutan, kestabilan fluktuasi, dan lainnya. Berhubung penilaian ini berdasarkan data otentik, maka data yang akan diproses harus didapat secara otentik dan benar. Misalnya data mengenai perkembangan nilai, data yang dimasukkan adalah selisih nilai pada bulan 12 dengan nilai pada bulan 1. Apabila digunakan range waktu 12 bulan pada suatu usulan investasi, usulan investasi lainnya juga harus menggunakan range waktu yang sama. Data dapat diperoleh dari internet, ataupun media lain yang kompeten dalam 
bidangnya masing-masing. Program ini hanya menerima input angka dari investor yang telah menghitung nilai perkembangan tiap usulan investasi. Ini dimaksudkan agar memungkinkan investor lebih leluasa menentukan berbagai jenis parameter yang ingin dibandingkan.

Hasil penilaian individu ataupun data tersebut, digunakan untuk menentukan nilai pairwise comparison pada tiap parameter. Nilai pada tiap usulan investasi yang sama akan dikelompokkan menjadi satu usulan investasi. Misalnya pada suatu parameter, nilai usulan $A=10 ; B=7 ; C=7 ; D=5$, maka pada pairwise comparison, menjadi $\mathrm{A}=10 ; \mathrm{B}, \mathrm{C}=7 ; \mathrm{D}=5$.

Apabila telah didapatkan nilai pairwise comparison dari input user, hirarki AHP akan dapat dilengkapi. Hirarki AHP yang dimaksud akan terlihat sebagai berikut (Gambar 3). Pada hirarki di atas, dapat dilihat bahwa pada parameter A yang berbobot 0.5 terdapat urutan usulan investasi A, BC, serta $\Theta$. Yang dapat disimpulkan dari hal ini adalah pada parameter A, usulan investasi yang paling tinggi adalah usulan $\mathrm{A}$, dilanjutkan dengan usulan investasi $\mathrm{B}$ serta $\mathrm{C}$ (yang memiliki tingkat prioritas yang sama). Lambang $\Theta$ menggantikan usulan investasi yang paling kecil.

\section{Analisis dan Perhitungan Bobot Dengan Metode Dempster Shafer}

Setelah mendapat nilai pairwise comparison, selanjutnya adalah menentukan nilai comparison matrix. Nilai pada pairwise comparison disusun menjadi matriks dua dimensi mengikuti aturan metode Dempster Shafer (Gambar 4). Maksud dari matriks di bawah adalah membentuk susunan matriks 2 dimensi yang memiliki diagonal utama bernilai 1 . Kemudian pada baris dan kolom terakhir diletakkan lambang $\Theta$.

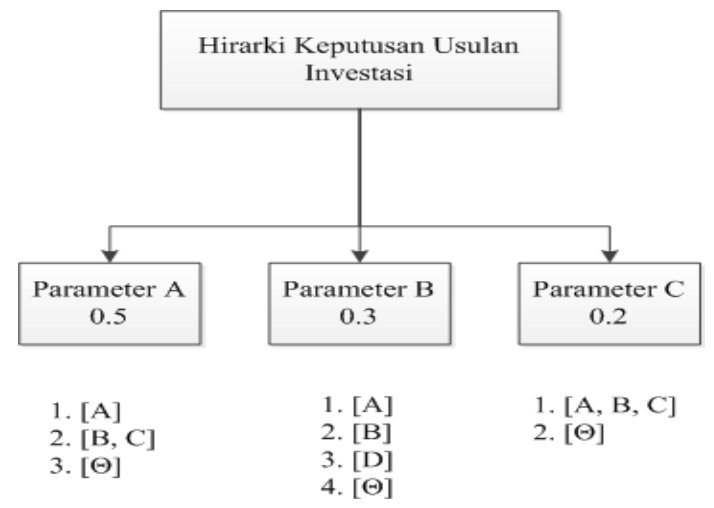

Gambar 3. Hirarki DS- Fuzzy AHP.

\begin{tabular}{|c|c|c|c|c|c|}
\hline & $S_{1}$ & $S_{2}$ & $\ldots$ & $S_{d}$ & $\Theta$ \\
\hline$\sigma_{1}$ & 1 & 0 & $\ldots$ & 0 & $p a_{1}$ \\
\hline$S_{2}$ & 0 & 1 & $\ldots$ & 0 & $p a_{2}$ \\
\hline$d=\cdots$ & $\vdots$ & $\vdots$ & $\because$ & $\vdots$ & $\vdots$ \\
\hline & 0 & 0 & $\cdots$ & 1 & $p a_{d}$ \\
\hline$\sigma$ & $1 /\left(p a_{1}\right)$ & $1 /\left(p a_{2}\right)$ & $\ldots$ & $1 /\left(p a_{d}\right)$ & 1 \\
\hline
\end{tabular}

Gambar 4. Matriks. 
Yang perlu diperhatikan adalah nilai terendah pada tiap usulan investasi akan diganti dengan $\Theta$. Misalnya pada contoh di atas, D digantikan dengan $\Theta$. Setelah disusun sedemikian rupa, selanjutnya menentukan nilai pada kolom $\Theta$, yaitu nilai pada pairwise comparison dikalikan dengan bobot pada tiap parameter. Setelah didapat nilai pada tiap kolom $\Theta$, dapat ditentukan nilai baris teta dengan cara $1 /$ nilai kolom $\Theta$. Lalu dilanjutkan dengan menentukan nilai priority vector pada tiap barisnya dengan rumus $\left((1 /\right.$ jumlah kolom $n)+(\text { teta pada } n / \text { jumlah kolom teta })^{*}(1 / \mathrm{jml}$ item $\left.)\right)$. Setelah didapat secara lengkap susunan comparison matrix dari tiap parameter, barulah masuk ke dalam tahapan Dempster's Rules of Combination. Tahapan ini adalah perkalian satu-satu tiap usulan investasi (gabungan) tiap parameter dari angka priority vector pada comparison matrix di tahapan sebelumnya. Rumus Dempster's Rule of Combination dapat dilihat seperti di bawah ini.

$$
\begin{aligned}
& m(\varnothing)=0 \text {, } \\
& m(A)=\frac{\sum_{A_{i} \cap B_{j}=A} m_{1}\left(A_{i}\right) m_{2}\left(B_{j}\right)}{1-K} \text {, jika } A \neq 0 \\
& K=\sum_{A_{i} \cap B_{j}=\emptyset} m_{1}\left(A_{i}\right) m_{2}\left(B_{j}\right)
\end{aligned}
$$

\section{Perancangan Algoritma Program Aplikasi Penentuan Portofolio Investasi dengan Metode DSF-AHP}

Untuk merancang program aplikasi penentuan portofolio investasi dengan metode Dempster Shafer Fuzzy, Analytical Hierarchy Process, digunakan Microsoft Visual C\# 2010, yang dapat dioperasikan pada sistem operasi yang dapat mengenal file berekstensi .exe (executable). Algoritma untuk program ini adalah sebagai berikut: (1) Input banyaknya usulan [2...5]; (2) Input nama usulan sesuai jumlah; (3) Output nomor beserta nama usulan + konfirmasi; (4) Input jumlah parameter [2...5]; (4) Input nama parameter sesuai jumlah; (6) Input bobot parameter sesuai dengan parameternya [jumlah harus 1]; (7) Output konfirmasi parameter beserta bobot dengan jumlah 1, apabila salah jumlah, ulang ke tahap 6; (8)Masuk perhitungan tiap parameter (sampai habis). Menentukan penilaian (individu/data): individu - langsung meminta input [1...10], data: (8.1) max memasukkan data awal dan data akhir.

Kemudian data tersebut dikurangi. Hasil selisih antara data akhir dengan data awal dibandingkan dengan jenis usulan lainnya. Hasil selisih terbesar mendapatkan penilaian tertinggi; mis: perkembangan ekonomi; (8.2) min - memasukkan data awal dan data akhir.

Kemudian data tersebut dikurangi. Hasil selisih antara data akhir dengan data awal dibandingkan dengan jenis usulan lainnya. Hasil selisih terkecil mendapatkan penilaian tertinggi; mis: kestabilan; (9) Menampilkan comparison matrix tiap parameter: (9.1) Matriks 2 dimensi (dengan array 2 dimensi) sesuai dengan rumus DFS-AHP (mengikuti pola); (9.2) Cari nilai kolom $\Theta$ (teta); pairwise comparison dikali bobot tiap parameter; (9.3) Tentukan nilai baris teta; 1/kolom $\Theta$; (9.4) Hitung jumlah tiap kolom; (9.5) Hitung nilai priority vector dengan rumus: $((1 /$ jumlah kolom $n)+($ teta pada $\mathrm{n} / \mathrm{jumlah}$ kolom teta)*(1/jml item)); (10) Menampilkan priority vector tiap parameter tiap pilihan (item); (11) Menghitung perkalian satu satu tiap item tiap parameter dari angka yang didapat pada priority vector; (12) Simpan angka hasil perkalian, dengan labelnya (irisanya). Bila tidak ada irisan, simpan sebagai variable kosong (k); (13) Hitung (1-k); (14) Bagi tiap hasil irisan dengan hasil (1-k); (15) Output angka beserta irisannya sebagai tingkat prioritas usulan investasi yang memungkinkan.

\section{Perancangan Program Aplikasi}

Pada tahapan ini akan dibuat rancangan proses, dan rancangan layar dari program aplikasi yang akan dibuat. Untuk aplikasi yang akan dibuat, digunakan bahasa pemrograman C\#. 


\section{Perancangan Proses}

Proses yang digunakan dalam aplikasi ini akan dijelaskan dalam flowchart pada Gambar 5 di bawah ini. Dan pada Gambar 6 di bawah ini akan ditampilkan state transition diagram dari proses pada program aplikasi. Gambar 7 di bawah ini menjelaskan use case diagram dari program aplikasi yang akan dirancang oleh penulis. Kemudian pada halaman selanjutnya, untuk menjelaskan rancangan program lebih lanjut akan disertakan keterangan tentang aplikasi program yang disajikan dalam bentuk diagram (Gambar 8). Hasil akhir dari perhitungan DSF-AHP berupa angka numerik beserta pilihan usulan investasinya (Gambar 9). Dari angka-angka tersebut, maka dapat dilihat kemungkinan investasi yang paling menguntungkan dari hasil input user. Semakin besar angka numerik yang terdapat pada hasil irisan kemungkinan jenis usulan investasi, semakin besar prioritas usulan investasi tersebut.

Kelebihan dari program ini adalah program ini dapat melakukan perhitungan metode DSFAHP dengan tingkat ketepatan yang sangat tinggi. Karena pada kenyataanya, akan sangat sulit untuk melakukan perhitungan metode DSF-AHP dengan cara manual. Karena sangat dibutuhkan ketelitian dan banyak melakukan proses yang relatif sama (perulangan) yang sebenarnya bisa dilakukan komputer dengan sangat cepat dan juga dengan tingkat ketelitian yang relatif lebih tinggi apabila dibandingkan dengan perhitungan manual. Jelas dapat dirasakan bahwa program ini sangat membantu para calon-calon investor untuk mempersingkat perhitungan metode DSF-AHP untuk menentukan urutan prioritas usulan investasi yang akan dipilih.

Selain itu, program ini juga membolehkan para user untuk menentukan jenis-jenis usulan investasi yang ingin dibandingkan seluas-luasnya. Disamping itu juga user diperbolehkan untuk menyertai berbagai macam parameter yang memungkinkan serta pembobotan tiap parameter yang tidak selalu sama antar satu parameter dengan parameter lainnya. Metode penilaiannya pun dirancang sedemikian rupa sehingga memungkinkan para user untuk memasukkan penilaian yang paling cocok untuk setiap parameter yang ingin dibandingkan. Seperti yang diketahui, bahwa jenis-jenis parameter sangatlah banyak dan bervariasi, sehingga sangatlah kurang kompeten dirasa oleh penulis apabila jenis parameter dibatasi.

Selain kelebihan yang disebutkan di atas, program ini tentunya memiliki kekurangan. Karena program ini dirancang untuk memberikan keleluasaan untuk user memasukkan berbagai macam jenis penilaian, maka penilaian berdasarkan data dirasa kurang spesifik dan kurang lengkap untuk melakukan perhitungan yang lebih jauh dan mendalam dengan melibatkan data yang banyak. 


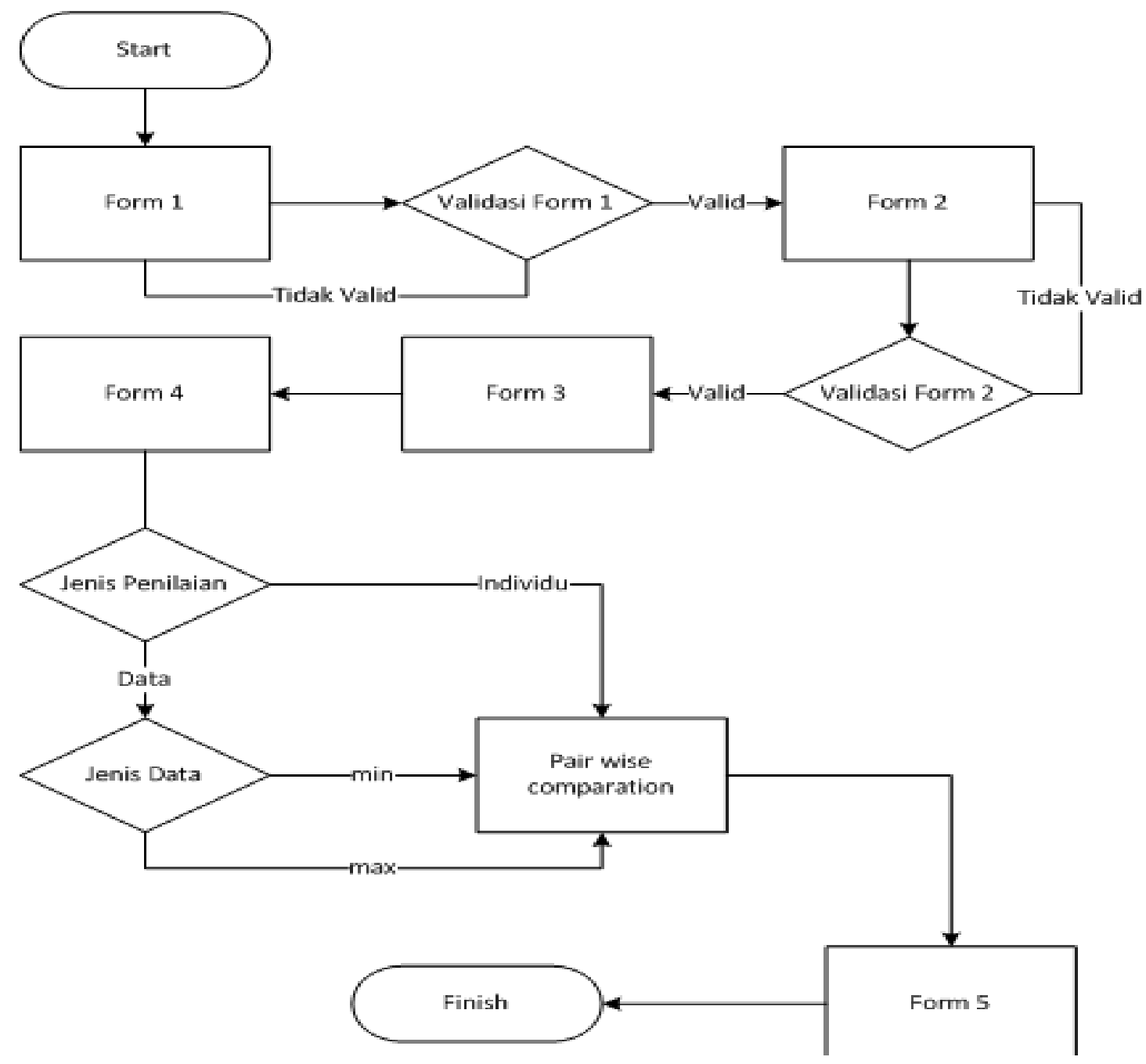

Gambar 5. Flowchart proses program. 


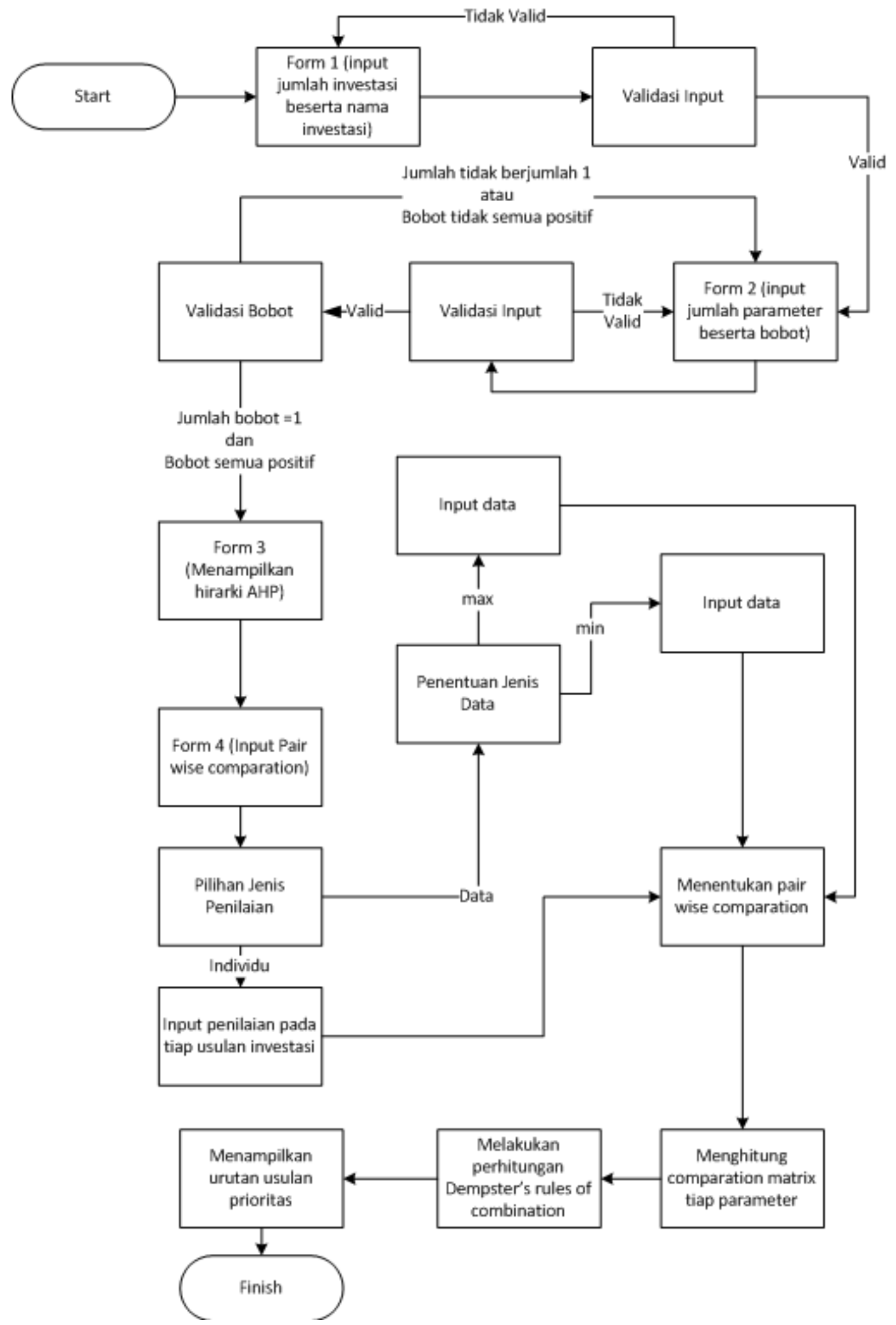

Gambar 6. State transition diagram program. 


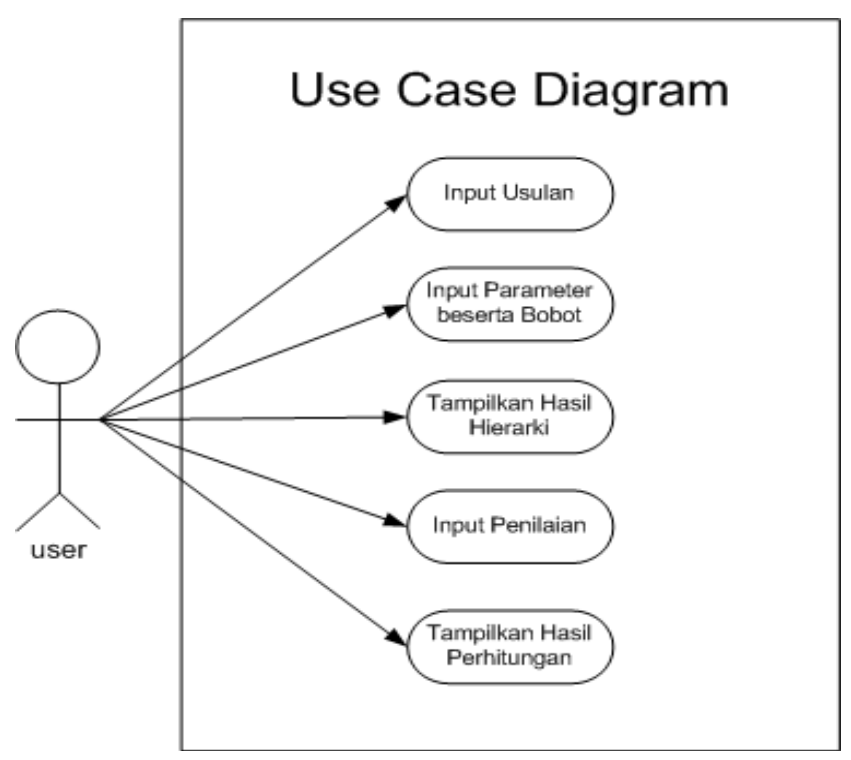

Gambar 7. Use case diagram.

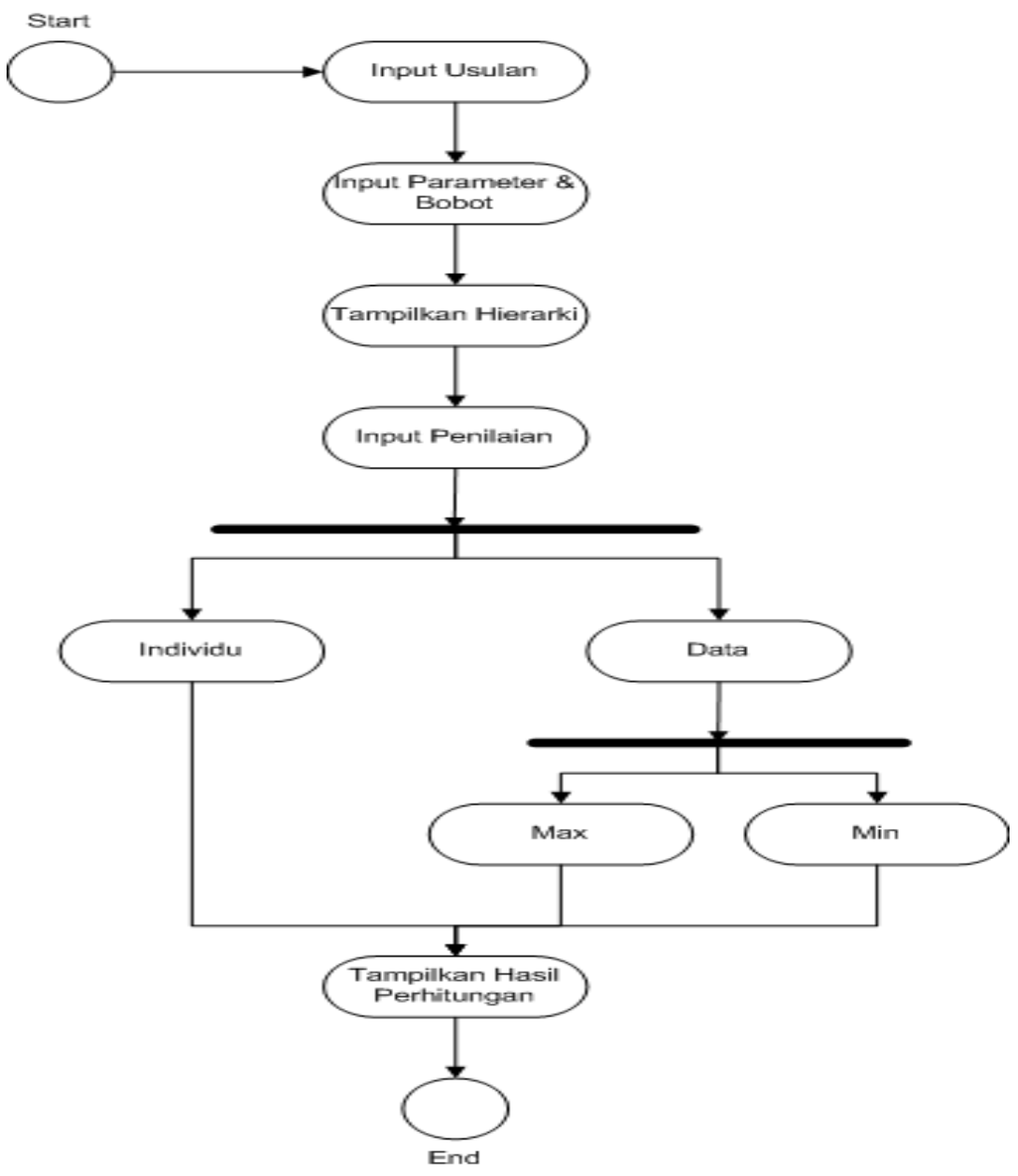

Gambar 8. Activity diagram. 


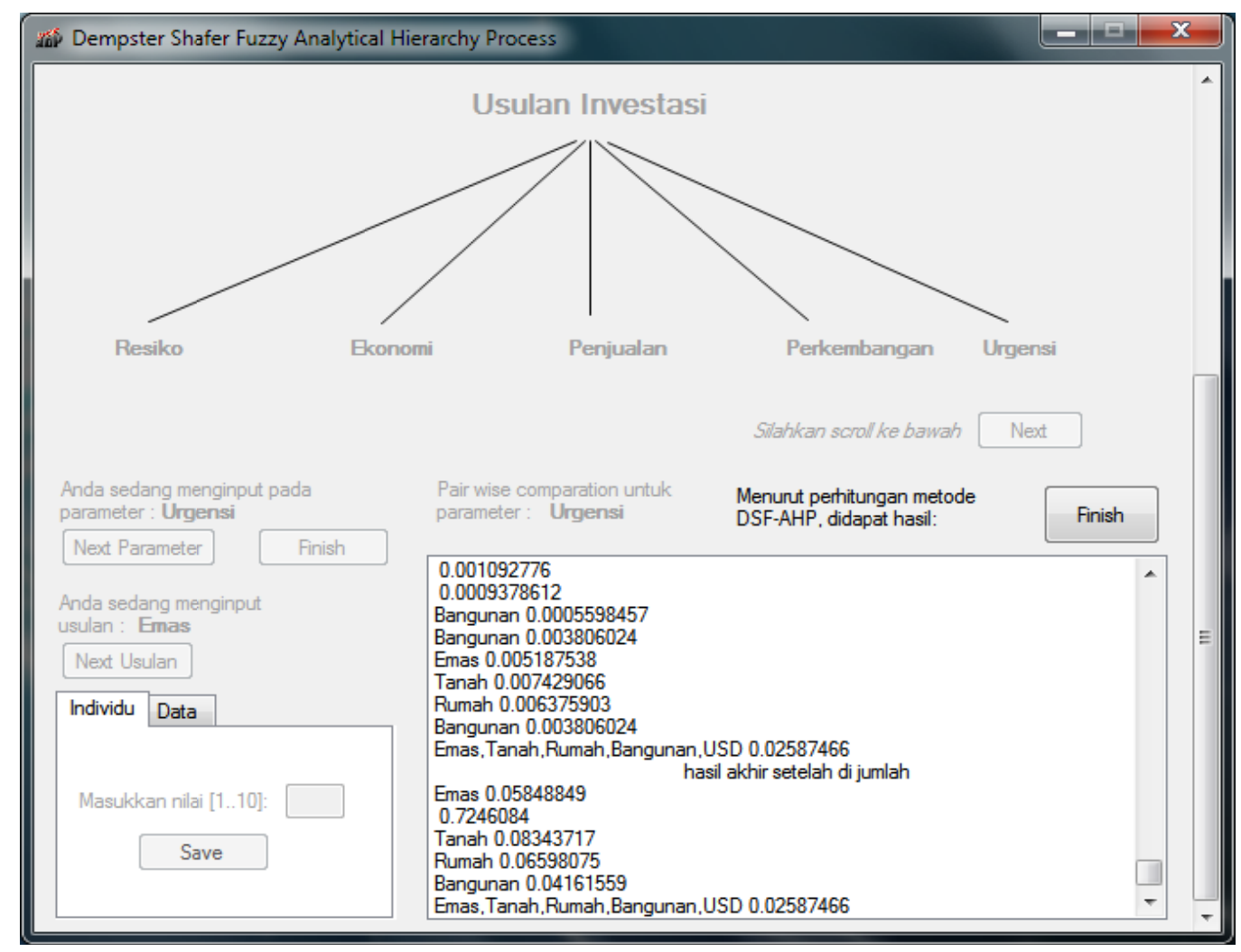

Gambar 9. Tampilan hasil perhitungan akhir DSF-AHP.

\section{PENUTUP}

Berikut adalah kesimpulan dari penelitian ini. Pertama, metode Dempster Shafer Fuzzy Analytical Hierarchy Process (DSF-AHP) dapat digunakan untuk menentukan urutan prioritas pada usulan investasi yang ingin dibandingkan untuk menentukan usulan investasi yang paling menguntungkan. Kedua, penerapan teknologi informasi pada metode DSF-AHP mempermudah para investor untuk memberikan pandangan serta prioritas pada setiap usulan investasi yang ingin dijadikan objek. Ketiga, tingkat kepercayaan pada hasil perhitungan metode DSF- AHP relatif lebih tinggi, karena melibatkan intuisi, pengalaman, serta data otentik secara bersamaan. Keempat, konsep logika Fuzzy dapat mengimplementasikan tingkat bobot, ketidakpastian, serta kecenderungan pada setiap hal penilaian non-mutlak kepada komputer. Kelima, metode Analytical Hierarchy Process dapat digunakan untuk mengambil keputusan efektif atas persoalan yang kompleks dengan cara menyederhanakan proses pengambilan keputusan dalam suatu susunan hirarki, serta memberi suatu nilai numerik pada pertimbangan subjektif tentang persoalan yang ingin diteliti.

Untuk Pengembangan kemungkinan jenis penilaian pada tiap usulan investasi di setiap parameter yang ada (selain jenis penilaian individu dan data). Pengembangan program ini menjadi khusus untuk usulan-usulan jenis investasi tertentu yang lebih spesifik, misalnya saham, index, kurs mata uang dan lainnya, sehingga dapat lebih bermanfaat. Adanya metode pelengkap atau bahkan metode baru yang lebih baik dalam memberikan solusi untuk menentukan urutan prioritas usulan investasi, sehingga tingkat keragu-raguan para investor untuk berinvestasi dapat ditekan seminimal mungkin. 


\section{DAFTAR PUSTAKA}

Latifah, S. (2005). Prinsip-Prinsip Dasar Analytical Hierarchy Process. Medan: Universitas Sumatera Utara.

Rahardjo, J., \& Sutapa, I. N. (2002). Aplikasi Fuzzy Analytical Hierarchy Process. Jurnal Teknik Industri, 4 (2), 82-92.

Saaty, Thomas L. (2005). Theory and Applications of the Analytic Network Process: Decision Making with Benefits, Opportunities, Costs, and Risks ( $2^{\text {nd }}$ ed.). Houston: RWS Publishing

Sudarsono, D. T. (2004). Penerapan Analytical Hierarchy Process (AHP) untuk Pemilihan Metode Audit PDE Oleh Auditor Internal. Komputer dan Sistem Intelijen, pp. 70-78. 